which are used by the Herald Office (with which Mr. Collins seems to be connected) to issue storim-warnings from the United States to Europe, no objection could be made against him. But $\mathrm{Mr}$. Collins is more ambitious, and makes some assertions which run against the most authenticated facts known to meteorology, and others which may be true, but ought yet to be proved, while Mr. Collins, without any proof whatever, seems to consider them quite well established.

I must first object to the absence of distinction between the seasons, which is so important a feature in storms, especially in lower latitudes. Mr. Collins seems not to know that the West India hurricanes and other destructive tropical storms are frequent only at certain seasons. This is quite enough to dispose of the author's assertion " that the conditions which combine to develop nearly all areas of low pressure are of equatorial origin." The most violent storms of Europe and the United States happen in the colder months of the year, when there are no storms in the tropical belt north of the equator (very few exceptions are known); besides the use of the word "equatorial" must be objected to as, so far as I know, no cyclone has ever originated between $5^{\circ}$ N.L. and $5^{\circ}$ S.L., at least, ${ }^{i}$ so that we may call the storms of the West Indies, the South Indian Ocean, about the Mascarenes, of the Bay of Bengal, \&c., tropical storms-because they certainly originate in the tropical belt--but certainly not equatorial. So far as Europe is concerned, there are some few cases in which West India hurricanes have reached it, but this is confined to the months of July to October. At the same time of the year it is not impossible that cyclones originating in the tropical belt of the Pacific may strike the Pacific coast of the United States. As to the storms mentioned by Mr. Collins, which strike the west coast of Mexico, pas 3 over the plateau, and thence into Southern Texas, I very much doubt their existence. In any case no storm of this kind has ever been followed on this route, and s) Mr. Collins ought to be rather careful in speaking of them. So far as I know, from books published about Mexico, and from personal information, no storms are experienced on the Mexican plateau.

The same absolute want of facts and general improbability can be urged against the storms which $\mathrm{Mr}$. Collins takes from the Asiatic continent to the Pacific and thence to the American continent. Here the distinction of the seasons is especially necessary, as all Eastern Asia is under the influence of monsoons or periodical winds. ${ }^{2}$ In winter, when pressure is so enormously high in the interior of Eastern Siberia, ${ }^{3}$ and the winds are northwest and north on the coast, that is, bring the cold dry air of the interior towards the Pacific Ocean, these conditions are favourable neither to local depressions nor to the propagation of European storms, which generally die out in Eastern Russia or Vestern Siberia. In summer the pressure is low in the interior of Asia, and air is constantly drawn from the Pacific Ocean to supply the deficiency towards the end of the rainy season or summer monsoon-in August to October is the time of the typhrons, that is, of the cyclones of the China Seas ; but they do not originate on the Asiatic continent, and only strike it on a very limited area, that is, the coast of Southern China. These typhoons may perhaps reach California, as the West India hurricanes reach Europe, but it is not yet proved that this has ever been the case.

I admit that in autumn, that is, September and October, storms may perhaps pass from the Asiatic continent to the Pacific, and thence to America; but in latitudes far to the north of those visited by the typhoons. At Yakutsk, in North-East Siberia, the prevailing winds of that season are west and south-west, the amount of cloud great, and rains frequent, if not abundant, while the temperature is generally above freezing-point to the middle of October. I consider it possible that Atlantic (European) storms may, at this season, travel over the whole of Northern Siberia and reach the Pacific. In winter this is impossible, on account of the low temperature and high pressure then existing in Siberia.

I resume a fex facts either well authenticated or very probable about storm-centres (cyclones) of the northern hemisphere.

I. By far the most of them originate in the middle latitnde $\left(35^{\circ}-65^{\circ}\right.$ N.) in Europe, North America, the Atlantic, and

'It wuld be too long to state why, there are no equat rial cyclones. I would advise Mr. Colli mosphère," by Guldberg and Mohn.

See "Winds of the Globe," by Coffin,-Snithsonian Contr.b. vsl. xx.

3 See Petermant's Mittheilungent, July, 1878, p. 259, and the short $\mathrm{n}$ tice in NArUkB, vol. xyiii. p. 288 .
Pacific. As to the three first-named regions it is abundantly proved by the observations we have already. As to the Pacific, we want the direct proof, because observations are too few. But nobody will doubt that, in conditions of climate so analy. gouts to those of the Aflantic cyclones do al so originate.

2. Cyclones are of much rarer occurrence in Asia, except the great summer depression, which is of a different nature, and remains the whole summer over the dryest parts of the continent.

3. Tropical cyclones are confined to a few months of the year, and even these seldom reach the latitudes north of $35^{\circ} \mathrm{N}$. Lastly, a few words about Mr. Bennett's storm-warnings. I do not doubt that some storms may reach Europe from America. But it is not at all certain that every storm that has passed from the eastern coast of America should reach Europe. This is the first difficulty in storm-warnings from America. The other is, that neither the path the storm will take nor its rate of progress can be known with certainty. Every one who has examined European and American synoptical maps will have noticed how different the paths of the centres are. So long as the storm can be followed on land, by means of numerous stations, a great approximation to certainty in predicting it is possible, as the durations are cartsed by certain pre-existing states of pressure, temperature, humidity, \&c. But how is this to be done on the ocean?

Meteorologists of great ability, especially Prof. Buys Ballot, have often advocated telegraph lines to the Azores and Iceland, so that these islands might serve as advanced guards to predict storms in Europe. At such a distance as they are from our continent they certainly could serve this purpose, as is clearly shown by the French Atlas Météorologique and Hoffmeyer's synoptical maps. As to American predictions for Europe, I must confess that most. European meteorologists are very doubtful about it. It is to be noticed also that, as storms are very frequent in western Europe, and as the rate of progress of storm-centres over the Atlantic is not accurately known, there may be a seeming success in American predictions which the facts, when accurately known, would not justify.

This is not meant to cast a shade on the spirit of enterprise of Mr. Bennett in organising the Herald weather predictions. The observations thus collected, or saved from oblivion, will certainly be useful, even if it be proved that storm-warnings from America are not reliable.

St. Petersburg

A. WOEIKOF

\section{A White Grouse}

WHEN shooting, yesterday, on the moors near Dunrobin, I fired at an ordinary grouse and killed it; just as it fell, another bird rose that seemed to be a ptarmigan, from the complete whiteness of its plumage; a third bird then rose, and was shot. The three were picked up not far from eacil other, and were al very fine bircls. It seemed strange that a ptarmigan should be so low; we were not very high above the sex, and far below the elevation affected by these birds. On examining it, it proved to be a very fine grouse, snowy white, with a few dark feathers in the tail and wings. It was not an albino; I think the eyes were dark. It is a very beautiful bird, has been sent off to Inverness to be stuffed, and will be preserved in the Dumrobin Museum.

No one here had seen a specimen of the white grouse before, and it excited considerable interest. No doubt it is only an accident, and its progeny, if it had any, would have been the ordinary grouse.

It may be less rare than I suppose, but you may deem its occurrence worthy notice in NATURE.

Dunrobin Castle, Sutherland, September 8 J. FAYRER

\section{Brehm's "Thierleben"}

IN last week's NATURE you have copied a drawing, "cobra charming," from Brehm's "Thierleben," presumably for its excellence. Permit me, however, to point out a most serious defect in its truthfulness-the relative proportions of the snakes to the charmers.

Take the youth blowing the horn to be 4 feet 6 inches in height (he could not be much less), the hoods of the cobras must be 8 to 9 inclies across. Now I will venture to say that a hood of $4 \frac{1}{2}$ inches across has never yet been measured, in a live specimen at least.

I cannot now lay my hands on a cobra skin I have, and give 